Portland State University

PDXScholar

\title{
Web 2.0, Synthetic Immersive Environments, and Mobile Resources for Language Education
}

Julie M. Sykes

Ana Oskoz

Steven L. Thorne

Portland State University, steven.thorne@pdx.edu

Follow this and additional works at: https://pdxscholar.library.pdx.edu/wll_fac

Part of the First and Second Language Acquisition Commons, Language Description and Documentation Commons, and the Semantics and Pragmatics Commons

Let us know how access to this document benefits you.

\section{Citation Details}

Sykes, J. M., Oskoz, A., \& Thorne, S. L. (2008). Web 2.0, Synthetic Immersive Environments, and Mobile Resources for Language Education. CALICO Journal, 25(3), 528-546.

This Article is brought to you for free and open access. It has been accepted for inclusion in World Languages and Literatures Faculty Publications and Presentations by an authorized administrator of PDXScholar. Please contact us if we can make this document more accessible: pdxscholar@pdx.edu. 


\title{
Web 2.0, Synthetic Immersive Environments, and Mobile Resources for Language Education
}

\author{
JULIE M. SYKES \\ University of Minnesota \\ Ana Oskoz \\ University of Maryland Baltimore County \\ SteVen L. ThORne \\ The Pennsylvania State University
}

\begin{abstract}
In light of the increasingly blurred line between mediated and nonmediated contexts for social, professional, and educational purposes, attention to the presence and use of innovative digital media is critical to the consideration of the future of computer-assisted language learning (CALL). This article reviews current trends in the use of mediated communication and offers a vision for near-future second and foreign language (L2) learning that utilizes emerging media as (a) meaningful contexts for $L 2$ language development and (b) a means for adding real world relevance to in-class uses of internet-mediated communication tools. In this article, we first explore a sampling of Web 2.0 technologies (e.g., blogs, wikis, and social bookmarking) related to collaborative content building and dissemination of information. We then consider three types of 3-dimensional virtual environments, including open social virtualities (such as Second Life and There), massively multiplayer online games (MMOGs) (e.g., World of Warcraft, Everquest, and Eve Online), and synthetic immersive environments (SIEs, i.e., visually rendered spaces which combine aspects of open social virtualities with goal-directed gaming models to address specific learning objectives). In particular, we report on SIEs as they might be used to foster interlanguage pragmatic development and briefly report on an existing project in this area. The ultimate goal is to spark future research and pedagogical innovation in these areas of emerging digital media in order to arrive at a greater understanding of the complexities involved in their integration with language learning in ways that will be most relevant to the communicative contexts of the 21st century.
\end{abstract}

\section{KEYWORDS}

Web 2.0, Online Virtual Worlds, Massively Multiplayer Online Games (MMOGs), Synthetic Immersive Environments (SIEs), Wiki, Blog, Social Bookmarking

\section{INTRODUCTION}

At present, education is entering a particularly critical stage that is marked by an urgent need to examine the role digitally mediated, collaborative tools play, not only as learning tools, but as authentic means of communication and relationship building. Concomitant with burgeoning numbers of internet users (approaching 1.25 billion individuals as of September 30, $2007)^{1}$ comes a parallel growth in quantity and variety of mediated expression, the everyday forms of participation in civic, professional, and social life, and, perhaps most profoundly, the

CALICO Journal, 25(3), p-p 528-546.

(C) 2008 CALICO Journal 
emergence of entirely new social formations that have surfaced only in, and through, internet mediation (for discussions, see Jenkins, 2006; Thorne, 2008a; Thorne \& Black, 2008).

The global internet use statistics presented above, supported by sociological research (e.g., Castells, 2004), suggest that, in many economically developed regions, one would find it difficult to conduct common professional and interpersonal activities without internet information and communication tools. ${ }^{2}$ In this sense, internet-mediated communication is no longer a supplement to, or practice arena for, communication in everyday life. Instead, it "is a high-stakes environment in its own right" (Thorne \& Payne, 2005, p. 372). That is, instead of merely simulating other modes of interaction, technology-mediated communication is, in and of itself, the real thing that operates as a critically important medium for all kinds of human interaction. In addition to the changes technology has precipitated in communicative functioning, there are cognitive implications related to the increased use of digital information and communication tools as well. Namely, recent research indicates both a qualitative and physiological shift in cognitive processes based on the prolific use of these tools in everyday life (e.g., Dror, 2007). Our premise, therefore, is that, in considering the future of computerassisted language learning (CALL), we should continue to leverage educationally oriented, computer-mediated activity, while also remaining aware of the transformational roles many of these collaborative tools play in meaningful language use, both inside and outside of the classroom. A corollary is that, in some cases, mastery of high-frequency and high-stakes mediated genres of communication should also form the explicit goal of educational practice.

This article reviews current trends in the use of digitally mediated communication and offers a vision for near-future second and foreign language learning (L2) that utilizes emerging media as (a) meaningful contexts for L2 language development and (b) a means for adding real world relevance to in-class uses of internet communication tools. In the following sections, we examine these issues in light of two genres of digital spaces-Web 2.0 technologies and multiuser, immersive virtual spaces. We first explore a sampling of three Web 2.0 technologies (i.e., wikis, blogs, social bookmarking) as related to transforming the practice of collaborative content building, dissemination, and categorization. This discussion will utilize specific examples drawn from projects related to L2 learning in Web 2.0 contexts. In the second half of the article, we consider three types of immersive virtual environments, including open social virtualities (e.g., Second Life or There), massively multiplayer online games (MMOGs) (the most prominent example of which is World of Warcraft), and synthetic immersive environments (SIEs, i.e., visually rendered spaces which combine attributes of open social virtualities with goal-directed gaming models to address specific learning objectives). In particular, we will focus on SIEs as they might be used to foster interlanguage pragmatic development and will briefly report on an existing project in this area. The ultimate goal of this article is to spark future research and pedagogical innovation in these Web 2.0 and SIErelated areas in order to arrive at a greater understanding of the complexities involved in the integration of digital media with language learning in ways that will be most relevant to the communicative contexts of the 21st century.

\section{WEB 2.0: WIKIS, BLOGS, AND SOCIAL BOOKMARKING}

With the introduction of Web 2.0 technologies, we have seen a noteworthy impact on the manners in which content is created, disseminated, and interpreted in society (Brown \& Adler, 2008; Levy \& Stone, 2006). Each of the Web 2.0 tools chosen for discussion in this article plays an important role in the understanding of a new conceptualization of social knowledge.

Wikis (i.e., collaborative, editable web spaces) facilitate the creation of content by groups of people, often resulting in the production of more accurate, diverse, and thorough 
informational texts. For example, one would be hard pressed to find an internet user not familiar with Wikipedia3 (http://www.wikipedia.org, currently reporting "more than 75,000 active contributors and 9,000,000 entries in more than 250 languages," Wikipedia, November 2007), a site that has been described as "collaborative writing that leverages collective intelligence for knowledge production in the public domain" (Lankshear \& Knobel, 2007, p. 17). While the value of the information on Wikipedia has recently been the focus of much debate (Jaschik, 2007), there is strong evidence that Wikipedia and related resources have transformed the ways in which knowledge is documented and shared on a global scale (Jenkins, 2008).

In conjunction with the collaborative content creation often found in wikis, blogs provide a new medium of individualized self-expression. A recent count by Technorati estimates the existence of more than 70 million active blogs with the number growing daily. Furthermore, real-time blogging through, for example, Twitter (http://twitter.com), is taking this individualized expression a step further by allowing opinions and commentary to be documented and shared synchronously. With increased access to the production and dissemination of information comes an increasing need to organize and personalize relevant information efficiently (Levy \& Stone, 2006). Social bookmarking sites, such as del.icio.us (http://del.icio. us), support this process by allowing users to catalogue, characterize, and share indexical resources to information.

While space limitations preclude further discussion, we wish to note the growing prominence of social computing networks (e.g., Facebook [http://www.facebook.com] and My Space [http://www.myspace.com]) and media self-publishing venues (e.g., Flickr [http:// www.flickr.com] and YouTube [http://www.youtube.com]) that allow users to personally connect, socially interact, and share media and activities with one another at a scale that is staggering. ${ }^{4}$ Facebook, for example, reports 57 million active users and an average of 250,000 new registered users daily since January 2007.

\section{WEB 2.0 AND L2 LEARNING}

In relation to the development of plurilingual competence, Web 2.0 tools support collaborative and individual text and multimedia production. Relatedly, they foster attention to aspects of language use that span from appropriate lexical choice to syntactic accuracy and from rhetorical style to textual cohesion and genre specificity. Furthermore, they have the potential to encourage awareness of the use of written language and visual expression as forms of representation that are rooted in, often pluralistic, linguistic and cultural conventions.

The aforementioned characteristics of Web 2.0 technologies help explain why reports on the use of wikis and blogs ${ }^{5}$ represent an emerging growth market in the economy of CALL research (e.g., Ducate \& Lomicka, 2005; Kost, 2007; Thorne \& Payne, 2005). Importantly, wikis and blogs are spaces in which students have the potential to move from the conventional epistemic stance of knowledge consumer to that of knowledge producer, and, in so doing, to shift also from mere participation in an educational community to contributive and co-constitutive roles in that community. We would underscore, however, that L2 and general educational uses of these technologies require critical awareness of media literacies and may provide both new resources as well as precipitate significant challenges to teachers and administrators (for a discussion, see Thorne \& Reinhardt, 2008). The remainder of this section reports on work currently underway in the CALL arena related to wikis, blogs, and social bookmarking. Each section further explores the unique role these tools can, and perhaps should, play in future language learning endeavors. Examples from current projects are included where available. 


\section{Wikis: Collaborative Content Creation}

Originally utilized by computer programmers and system designers, wikis have become popular venues for collaboration and communication in a variety of contexts, including the education arena, at both the K-12 and university levels (Farabaugh, 2007; Farabaugh, Farabaugh \& Freeland, 2005; Kost, 2007; Oskoz \& Elola, 2008; Wang et al., 2005). In part, educators' interest in the use of wikis likely "derives from the facility [they] offer [for] talking to others, regardless of the distance, and the opportunity [they] provide to gather information. Using [them], we feel connected, both to the people and to various contexts of our world" (Farabaugh, 2007, p. 42). Furthermore, wikis are readily accessible and are low or no cost for noncommercial (e.g., educational or nonprofit) use. ${ }^{6}$ Increasingly, open source (e.g., Moodle) and commercial (e.g., WebCT/Blackboard) course management systems (CMSs) now include integrated wiki and blog spaces, making them more readily available to practitioners already using such systems.

Early reports on the use of wikis in the L2 classroom have been primarily descriptive and exploratory in nature (Godwin-Jones, 2003; Thorne \& Payne, 2005), but a number of projects currently underway have documented innovative uses of wikis in the L2 classroom. These include the application of wikis to connect methodology classes among universities (Lomicka, Lord, Ducate, \& Arnold, 2007), to examine students' content and composition development (Oskoz \& Elola, 2008), and to assess learners' language use as part of their experience in writing classes (Kost, 2007). From an examination of these studies, as well as the more general literature on wikis, two attributes of this mediated context emerge as especially applicable to the CALL arena. These include a reconceptualization of authorship as well as changes to approaches to the writing process as a whole.

The blurring of historical notions of authorship that emerge as a function of collaborative writing in a universal write-access wiki space revises the conventional author-reader relationship; witness the lack of explicitly defined authorship on sites such as Wikipedia to name the most prominent example (see Thorne, 2008b, for a discussion). Fully utilizing wikis in the L2 classroom requires recognition of the learning that can take place through, and as a result of, the collaborative creation of one final product (Brown \& Adler, 2008). This has an impact not only on the notion of individualized scholarship, but also the created product as a whole.

In terms of assessment and insight into the writing process, a useful feature for language educators is the ability to explicitly track all registered user contributions to a wiki document (e.g., additions, deletions, alterations, etc.). This feature makes visible many aspects of the historical evolution of a text as well as the content of individual user contributions. Learners themselves can use document tracking features to examine the evolution of a text, potentially enhancing their ability to objectively monitor and control their learning processes. As stated by Farabaugh, "the discussion tend[s] to be evolving and democratic ... with each participant in turn taking the opportunity to shape the 'reified' experience" (2007, p. 45). In essence, knowledge building is not only focused on developing a final product; also highlighted are the turn-by-turn dynamics of scholarly authorship within an "open source epistemology" (Lankshear \& Knobel, 2007, p. 18).

The collaborative value of wikis is further increased when accompanied by the use of web-based voice applications such as the commercial tools Skype, Skype TM, or Voice Direct. Adding a synchronous voice application to the asynchronous collaboration of wikis provides another layer of complexity and richness to students' work and increases the level of accountability for the participants (Oskoz \& Elola, 2008). Collaboration goes beyond the editing of sentences, organization of paragraphs, and addition of content. Given that the final product is a representation of all of those involved, the synchronous voice discussion becomes a ne- 
gotiation of ideas, more closely mimicking collaborative scenarios that often happen in the nonacademic world (e.g., Brown \& Adler, 2008; Jenkins, 2006). From a pedagogical point of view, instructors can design activities that engage learners, both synchronously and asynchronously, to enable collaborative engagement on a more complex level. To take an example from one of our institutions, students in advanced writing classes in Spanish participate in research projects in which pairs of students collaborate in the development of content and language learning related tasks via wiki. While students complete most of the work and the revisions in the wiki, they have the opportunity to fine tune and discuss any content or linguistic concerns synchronously by using tools such as Voice Direct. Through archival searches of these online discussions, a record of the collaborative process is created that can be easily accessed and reviewed.

From a research point of view, the use of wikis, in conjunction with voice (or written) chat, supplies a large amount of data regarding students' collaboration across drafts, the depth of students' discussions with voice/written chat, and organizational, linguistic and content related differences between first and final drafts (Oskoz \& Elola, 2008). This information can provide additional insights into the complex L2 writing process, which, in turn, can inform pedagogical applications in the classroom.

\section{Blogs: Self-expression and (the Potential for) Enhanced Readership}

Blogs come in many shapes and sizes and have evolved as a set of "social and informational phenomena that include mainstream media as well as grassroots and watchdog news reporting, thematic and topic-specific amateur and professional observations, business and commercial information outlets, and, of course, the 'public' journaling of one's 'private' life" (Thorne \& Payne, 2005, p. 382). They are free (e.g., Blogger.com [https://www.blogger.com/ start]), easy to create (i.e., often a matter of merely entering content and uploading), and customizable (making them attractive to advanced users). In addition, they provide a space in the public domain to which information can be added instantaneously (Richardson, 2006) and made available to a global audience. ${ }^{7}$ Thus, blogs are especially useful for encouraging individual (and less frequently, group) authorship that is relevant to a larger, interactive community.

Blogs are receiving increasingly more attention in CALL research and second language instruction (e.g., Bloch, 2007; Ducate \& Lomicka, 2005; Elola \& Oskoz, 2008; Fidalgo-Eick, 2006) as primarily individual authoring environments. While blogs are often richly interlinked with other interactive digital spaces, blogs tend to be highly personal and have been described as "I, I, me-me-me" environments due to the fact that they are typically controlled by a single person and explicitly reflect that individual's point of view (Thorne \& Payne, 2005, p. 382). Their potential to enhance L2 writing skills through meaningful tasks and extended readership is often the subject of attention.

Despite the individually oriented perspective often associated with blogging, their use also offers significant opportunities to cultivate interaction. Readers can respond to writers' entries with comments that can result in de facto threaded discussions (Campbell, 2003). Student maintenance of individual journals by participating in blog communities, different from essays written to an unknown or overly narrow audience (e.g., the instructor), provides students with a sense of authorial purpose (Fidalgo-Eick, 2006). Moreover, blogs can be used to enhance students' reading and writing, both in their native language and the target language(s) (Ducate \& Lomicka, 2005). Furthermore, students can access entries on different topics by experts and other learners as well as explore links referenced within a blog. Learners 
can also read blogs written by individuals around the world, supporting the analysis of-and interaction with-cultural information viewed as a form of legitimate cultural eavesdropping.

In addition, blogs can be envisioned as a tool for students to develop intercultural communicative competence, defined as openness to difference and a capacity to contingently and dynamically interact with members of other speech communities and cultures (e.g., Byram, 2000; Belz \& Thorne, 2006; Thorne, 2006). In a recent project (Elola \& Oskoz, 2008), blogs were used to connect residential foreign language students with international partners. Following discussion of a series of tasks related to family, health, art, and urban living, students, working primarily in pods of four (two students in the US and two students in Spain) presented evidence of intercultural competence. Overall, students found the experience to be successful and both groups perceived that blogging had a positive effect in their intercultural competence development.

\section{Alternative Forms of Blogging}

Current blogging practices involve more than the written word. Three popular forms of multimedia blogging-audioblogging, moblogging, and vloging-include the primary objective of blogging through multimedia (i.e., audiofiles, pictures, and videos) as an addition to, or replacement of, textual postings. Similar to text blog posts, multimedia blogs are organized by the time and date posted. Moblogging, for its part, allows users to upload pictures taken from cell phones, PDAs, and digital cameras, presenting an opportunity for real-time documentation and charting. Finally, vlogs support the addition of video, usually accompanied by text, images, and additional contextual information. Paraphrasing Godwin-Jones (2005), moblogging and vlogs are particularly compelling at a time in which so many cell phones have built in digital cameras and the capacity to create video clips. Given the facility to download MP3 or other audio files and the large number of students who own cell phones, these three variables bring new possibilities and projects to the L2 classroom. For example, in study abroad contexts, without the need to wait for access to a computer, students upload images and text directly from their cell phones, thus sharing more vividly and rapidly their experiences with others, be it family or classmates. These formats have been little explored in L2 education research but are growing in popularity with campus study abroad offices and organizations (a Google search on the query "study abroad blogs" returned 277,000 hits, the first 5 pages of which were nearly all relevant).

\section{Social Bookmarking: The Social Organization of Collective Knowledge}

With the explosion of shared content available in these emerging digital spaces, the ability to categorize and annotate information that is meaningful and relevant to an individual is important (Levy \& Stone, 2006). However, due to the sheer volume of content available in digital spaces today, it is impractical (and likely impossible) to effectively manage the information at a local level (e.g., each individual user). Therefore, while the word "bookmarking" does not necessarily make us think of collaboration, social bookmarking, in essence, is the collaborative management of digital content. Instead of individually bookmarking each site of collective interest, social bookmarking allows one to annotate in a minimally designed webpage such as in del.icio.us URLs to different web pages. Below each URL, the user is able to provide a small description of the webpage content where the user(s) select words as tags. ${ }^{8}$

The benefits of using social bookmarking as a research or instructional tool include: (a) creating an "outboard memory," a page that stores links that could otherwise get lost in an array of emails and printouts; (b) connecting with people who share the same interests and who 
could become potential collaborators; (c) clustering tags which reveal unique combinations of an individual's research themes; (d) creating a multiauthored, bookmarked page that might ultimately benefit the entire team when working on a project; and (e) providing insights into the owner (owners') research (Alexander, 2006). Social bookmarking creates a space where students can share their personal and professional inquiries. Sites such as del.icio.us provide the possibility of creating private networks localizable to students in a class, enabling the creation of a bank of resources to which everybody would have access. ${ }^{9}$ The benefits of social bookmarking go beyond the sharing of information among users. As with the aforementioned communication environments described above, its benefits are maximized when used in conjunction with other tools, for example the linking of social bookmarking with blog and wiki projects. ${ }^{10}$

In general, we consider the Web 2.0 tools presented in this article as essential to the transformation from individual to collective content creation, dissemination, and categorization. Future CALL research and L2 pedagogy would benefit from continued exploration of these tools as serious, relevant contexts for the creation and shaping of knowledge in meaningful, real-world contexts.

\section{ONLINE VIRTUAL WORLDS: OPEN SOCIAL SPACES, MASSIVELY MULTIPLAYER ON- LINE GAMES, AND SYNTHENTIC IMMERSIVE ENVIRONMENTS}

An important area that warrants significant attention in considering the relevance of mediated contexts are the realms of open social spaces (e.g., Second Life, There, and Active Worlds), massively multiplayer online gaming spaces (MMOGs) (e.g., World of Warcraft, Everquest, and Eve Online), and synthetic immersive environments (SIEs) (e.g., Croquelandia and ZON). The commercial endeavors in this context form a billion dollar empire and engage participants from all over the world. Recently, educational researchers have begun to assess these interactional spaces and gaming models as beneficial for learning (e.g., de Freitas, 2006; Gee, 2003, 2005; Jenkins \& Squire, 2004; National Summit on Educational Gaming, 2005; Prensky, 2001; Steinkuelher, 2004, 2007), and, more specifically, for achieving communicative and intercultural competence (e.g., Bryant, 2006; García-Carbonell, Montero, Rising, \& Watts, 2001; Thorne, 2008c; Thorne \& Black, 2007, 2008). Mediated experiences in different online social and gaming worlds allow users to experiment and interact with a wide variety of norms of communication and social interaction (e.g., Steinkuehler, 2006). Thus, each type of visually rendered virtual space presents distinct possibilities for language development based on the affordances, constraints, and unique interactional opportunities of the space itself. In the discussion to follow, we first address considerations of communicative norms within various types of online immersive worlds. We then explore the use of SIEs for L2 learning with specific reference to a project that targets the complex issue of interlanguage pragmatic development. ${ }^{11}$

\section{Communicative Norms in Online Virtual Worlds}

In thinking about the complex, collaborative nature of immersive spaces, it is critical to examine not only the features unique to each type of space, but also the communicative norms and practices associated with their use. Examining why and how construction and negotiation of communicative functions occur in intercultural language learning through computermediated communication (CMC), Thorne (2003) presents a cultural-historical framework for understanding how internet-based tools mediate communication (see also Lantolf \& Thorne, 2006). Based on this framework, Thorne postulates that "digital communication technologies 
have made possible substantive aesthetic shifts in human communicative practices" and argues that such practices emerge within distinctive cultures-of-use-that is, the unity of local and contingent aspects of interaction with "the historically sedimented characteristics that accrue to a [computer-mediated-communication] tool from its everyday use" $(2003$, p. 40). The historically developed cultures-of-use of a mediated communication environment, involving norms and expectations of appropriate language use, shape interactional dynamics and, by extension, the forms of language development and literacy engagement taking place in these contexts (see also Thorne, 2000).

Historically, the field of second language acquisition has seen an increasing level of importance placed on communicative norms as part of evolving models of communicative competence (Bachman, 1997; Canale \& Swain, 1980; Hymes, 1972; Thorne, 2006 ${ }^{12}$ ). Immersive modalities offer significant opportunities for engaged interaction and language socialization within specific genres and communicative norms. Attention to the relationship between innovative mediated communication technologies and the development of advanced language skills, such as pragmatics, should be considered, not only in terms of how they function as learning tools, but also as relevant interactive contexts in and of themselves. Thus, when considering any mediated environment, it is critical to place value on the inherent norms of the interactive space itself as well as the application of learned skills to other communicative contexts.

Full participation in virtually rendered spaces requires pragmatic control of the communicative norms local to a specific online community as well as mastery of the interface and virtual topography. Users of Second Life, for example, must learn a designated set of in-world features before they are permitted to navigate away from "Orientation Island." Moreover, to be a highly skilled player in World of Warcraft, one must not only be able to complete quests, gain assets, and navigate through three continents of geographic space, but also to interact with others in an appropriate manner utilizing the norms established by expert players of the game. This point will be elaborated shortly.

To add further complexity, participants may take on numerous identities in immersive spaces through careful manipulation of sociopragmatic factors as they carry out and creatively transform roles they visually embody in the virtual space (Gee, 2003, 2005; Prensky, 2001). For example, in Second Life, an open social space designed as a simulation of "life," users can select the gender of their avatar, design their own clothing, and modify their behavior based on, for example, location or the presence/absence of other participants. Behavior in Second Life can be, and should be, tailored to suit a variety of social contexts such as the tropical island bar, classroom, or commercial, high-power board room of a company on virtual Main Street. Moreover, experienced players are quite adept at identifying new users based on the appearance of their avatar (Sadler, 2007).

Players of MMOGs can take this experimentation one step further by selecting a race, class, or profession. In World of Warcraft, to take an example from the most widely played MMOG (with over 9,000,000 players worldwide), users begin the game by selecting a race (which influences geographical area, game-suggested personality, and other social features) as well as a class (which influences abilities and the manner in which the game is played). Once this selection has been made, a user's avatar is then constrained by the societal norms of that race in Azeroth (the simulated world in which the characters live). For example, Night Elves are described in the official game documentation as a race having more sophisticated personalities with a tendency to make dry jokes whereas Gnomes are depicted as the "nerdy" race that is marked with extreme intelligence and mechanical abilities. Each of these constraints is game suggested, yet user selected and enacted (or not, as is frequently the case). 
In MMOGs such as World of Warcraft, it is common for users to create two or more characters (known as 'alts' or 'toons') in order to experience the game from different perspectives. This seems to indicate that social experimentation is an inherent characteristic of these spaces. In addition to experimenting with roles and personalities, learners can also experiment in terms of gesture, physical context, audio enhancement, and transferring of assets within the various types of immersive spaces. As Gee suggests, "[g]ames are an invitation to play out different sides of our desires, feelings, values, fears, fantasies, and identities" (2005, p. 70). In relation to language learning, such opportunities for identity play precipitate sociopragmatic considerations that can involve gesture and personal space (e.g., Rosenbloom, 2006), political action (e.g., Sawyer, 2005; Second Life Herald 2006, 2007), critique and coconstruction of "culture" (e.g., Mistral, 2007), caretaking (Kushner, 2006), emotional connection with others and with the game space (e.g., Slater et al., 2006), sexual encounters (e.g., Cheng, 2006), and commerce (e.g., Shamoon, 2006).

\section{Virtual Social Spaces and Massively Multiplayer Online Gaming Spaces}

While there is a growing body of research addressing the use of Second Life in education, up to this point (see de Freitas, 2006, for a review), relatively little research has specifically addressed the use of MMOGs for L2 language development. In a preliminary analysis of these issues, Thorne (2008c) analyzes intercultural communication occurring in MMOGs as related to other internet-mediated communication modalities. A detailed analysis of an interaction between an expert speaker of English living in the US and an expert speaker of Russian living in the Ukraine indicates evidence of a number of positive assets for language learning (e.g., natural, unscripted interaction, emotional bond with the interlocutor, reciprocal alterations in expert status, explicit other- and self-correction, extended repair sequences, and exhibited motivation for language learning). Additionally, the interaction represented in this case study demonstrated numerous complex communicative functions such as solidarity building, greeting and leave taking, apologizing, and requesting (see also Nardi, Ly, \& Harris, 2007). Despite the limited work in this area, the inherent characteristics of both open virtual spaces and MMOGs offer numerous potential benefits for the development of complex communicative skills, such as pragmatics, in a second language. ${ }^{13}$ The following section describes a project currently underway aimed at leveraging the possibilities of immersive spaces for language learning.

\section{Synthetic Immersive Environments}

SIEs represent a unique variety of online immersive space that is carefully designed to function as a social space while, at the same time, incorporating the beneficial attributes of MMOG models. In other words, SIEs are engineered spaces which integrate the many benefits of online gaming to produce explicit, educationally related outcomes in simulated, relevant interactional contexts (Sykes, 2008). SIEs carry significant potential in that they allow creators to target specific skills and educational objectives, while creating a meaningful collaborative space in which learners themselves are at the center of their own learning.

A large-scale research project which entails the creation, implementation, and analysis of the first SIE targeted at attaining advanced L2 skills is currently underway (Sykes, 2008). The Croquelandia space ${ }^{14}$ is an SIE designed for the learning of Spanish pragmatics in which learners are immersed in a 3-dimensional, graphically rich social space that emulates various regions of the "real" Spanish-speaking world. During their time in Croquelandia, learners are engaged in a variety of game-like, goal-directed activities (e.g., quests) designed to provide 
behavior-based corrective feedback to users through interaction with non-player characters (NPCs), native speakers, and other group members. Learners are able to practice in the SIE in order to improve their pragmatic competence in a low-risk, yet emotionally engaging, immersive space. Interaction with, and within, this SIE carries the ultimate goal of enhancing learners' ability to deal with various pragmatic features of L2 Spanish. Initial learner perception and outcome data indicate a positive effect of the use of SIEs for pragmatic development. The following section explores some of the advantages and disadvantages of the use of SIEs for learning L2 communicative norms, especially considerations relevant to pragmatics.

\section{THE ADVANTAGES AND DISADVANTAGES OF SIES FOR L2 PRAGMATIC LEARNING}

\section{Advantages}

Considering the complexity of the issues inherent in the internet-mediated communicative contexts themselves as well as the numerous pragmalinguistic and sociopragmatic factors influencing pragmatic appropriateness, it might appear impossible to harness this technological tool for L2 pragmatic learning. However, the whole might be less complex than all of its individual components. Research has shown that pragmatics is indeed teachable and should be included in L2 language learning (Cohen, 1996; Kasper, 1997; LoCastro, 2003; Rose \& Kasper, 2001; Rose, 2005). Furthermore, internet-mediated tools offer immense potential to overcome some of the inherent difficulties in teaching pragmatics (Sykes, 2005). Some of these difficulties include: (a) individual personality differences and sensitivity to certain contextual factors influencing the interaction (Bardovi-Harlig, 2001; Kasper, 1997), (b) assessment and feedback challenges (Cohen, 2004; Roever, 2004; Salaberry \& Cohen, 2006), and (c) immense variation (dialect, social, individual) (Márquez-Reiter \& Placencia, 2005).

One of the biggest advantages of using SIEs for learning pragmatics, as well as other complex communicative norms and functions, is their flexibility and built-in complexity. In other words, it is an internet-mediated modality which encourages the use of an integrated set of complex features to learn about complex language functions (i.e., pragmatics) in a realistic amount of time, not something that is merely created for a learning exercise. Gee (2003) describes the mechanism driving games, which is equally applicable to SIEs,

So here we are with something that is long, hard, and challenging. However, you cannot play a game if you cannot learn it. ... Of course, designers could keep making them shorter and simpler to facilitate learning. ... But, no, in this case, game designers keep making the games longer and more challenging, and still manage to get them learned. (p. 6)

This is much like pragmatics. The more you know, the more difficult it becomes, and the longer it takes to truly master the necessary pragmalinguistic and sociopragmatic skills. ${ }^{15}$ SIEs provide a mechanism for making this a possible and realistic endeavor. This complexity also makes SIEs unique from other types of internet-mediated environments.

\section{Simulated Roles and Identities}

As noted in the previous discussion regarding online immersive spaces, one of the most positive assets for L2 pragmatic learning is the possibility to take on numerous, simulated identities and participant roles. In doing so, learners are able to experiment and practice pragmatic functions in diverse social contexts and settings. In SIEs, assumed participant roles move a step beyond those found in a synchronous CMC environment. Not only can learners simulate 
and manipulate the roles they are taking on, they can also embody them in the visually simulated space (Gee, 2003, 2005; Prensky, 2001). Through this experimentation, the goal is that learners begin to understand the impact language has on their level of success (high or low) in specific communicative contexts. Furthermore, the intention is that they will also start to integrate the pragmatic skills acquired in the SIE into their repertoire for use in nonmediated interaction and other digital contexts.

\section{Emotional Connection}

Another important advantage of SIEs is the emotional connection users often feel in response to the environment. This is especially beneficial in SIEs because the virtual environment itself can be constructed in ways that are relevant for a specific population of learners. For example, Croquelandia utilizes digital models created from photographs taken in geographical locations throughout the Spanish-speaking world (e.g., Otavalo, Ecuador, and Merida, Mexico). Retrospective interviews with the participants indicate that this "simulated realism" was especially impressive to learners involved in the project because it allowed them to feel like they were "really there" (Sykes, 2008).

This emotional connection with the content is an important benefit of the SIE space. Research has shown that immersive spaces are highly engaging and produce emotions of "real" consequence (Prensky, 2001; Slater et al., 2006; Wilcox, Allison, Elfassy, \& Grelik, 2006). It allows the opportunity for learners to feel the results of their actions without causing real-world harm to the people around them. de Freitas (2006) notes that "By creating games as metaphors, children and adults can utilize role play and narrative forms to imagine and empathize with other people, events from history, or with potential scenarios in the future and to experiment and rehearse skills in safe, protected environments" (p. 6). They also can begin to see the world around them reflectively and thoughtfully, making pragmatic features more important to their perceived success. This advantage is similar to that found in the telecollaboration studies using asynchronous CMC and synchronous CMC (Belz, 2003; Furstenberg, Levet, English, \& Maillet, 2001; Thorne, 2003) in which learners build emotional bonds (positive or negative) with their collaborative partners. In SIEs, these emotional connections may motivate learners to continue practicing so they can successfully cultivate their relationships with other human beings, either collaboratively in the virtual space or in other contexts within the Spanish-speaking world.

\section{Authentic or Low-Risk Practice}

An additionally noteworthy attribute of SIEs is the extensive opportunity to practice. Practice and hypothesizing is an important component of L2 pragmatic learning. First of all, learners have the opportunity to interact with native speakers in a nonthreatening environment where they already share common ground (i.e., the SIE itself). As observed by Thorne (2008c) in an analysis of discourse between a Russian student and an American student, bonds are built fairly quickly and include interaction around the space as well as aspects of the world outside of the SIE. This can lead to a number of practice opportunities by bringing together interlocutors from around the world, especially in large-scale commercial games.

Another advantage is the low-risk practice opportunities provided through interaction with NPCs (de Freitas, 2006; Gee, 2003, 2005; Mistral, 2007). This is an advantage for L2 learning because high-stakes speech acts, such as apologizing, can be performed without offending "real" interlocutors. Yet, at the same time, learners can feel the impact of their errors 
based on elements built into the space (e.g., lost assets, fewer invitations, angry NPCs). Thus, different types of practice can provide advantages to L2 pragmatic learning in a number of ways, either through interaction with other human beings or interaction with elements built into the spaces themselves.

\section{Disadvantages}

Despite the many potential benefits offered by SIEs for pragmatic learning, it is important to discuss the drawbacks as well. The biggest potential disadvantage in SIEs is the danger of learning the pragmatics of the space and not necessarily skills of the L2 itself. As previously mentioned, online immersive spaces are constrained by, and create, their own communicative norms. Thus, two people who are extremely close and get along very well in an SIE may not necessarily be able to transfer that relationship, and those in-game communication repertoires, to face-to-face communication. Gee (2003) describes the case of a player who had reached a very high level in a MMOG only to have his character killed off. In this particular game, the only way to be resurrected is to be invited back in by another player. The player in question posted numerous requests including his home telephone number, and, eventually, someone helped him get back in. However, it took a great deal of time for this to happen and only a few players were willing to help. In other words, the communicative norms maintained in the MMOG did not carry into communicative contexts outside of the immersive world. In this case, the request was granted, but there was no guarantee outside of the playing space that the same type of solidarity existed in other contexts. A way to overcome this drawback is to continue to focus on skills for L2 pragmatic performance that enable learners to deal with a variety of contextual and mediated (as well as nonmediated) situations.

Another disadvantage of using online immersive worlds for L2 learning, especially applicable in the case of multimillion dollar immersive environments such as Second Life and World of Warcraft, is the stigma educators might have about embracing the positive aspects of the spaces themselves. Gee $(2003,2005)$ comments extensively on the perceptions that many have about the representation of violence or gender in the learning spaces. While he does not embrace many of the criticisms, the issues themselves could create difficulties when implementing these learning tools in the educational setting. (For a discussion of the evolving role of gender and gaming, see Cassell \& Jenkins, 1998).

\section{CONCLUSION}

Using Web 2.0 tools and various forms of online immersive worlds suggest a number of profound transformations to traditional approaches for second language education. In each of the contexts described above, students' agency-defined here as the socioculturally mediated capacity to act (based on Ahearn, 2001)-has the potential to evolve beyond the confines of the subject-position associated with the conventional institutional identity of 'student.' Intrepid uses of new media fray the boundaries separating study from play, student from player, and information consumer from knowledge producer. In many of these contexts, from social bookmarking and wiki use to MMOG play, expertise is distributed across participants engaged in multiple systems of activity that relate to the local enterprise at hand. Additionally, when new media is put to wise use, we see tremendous potential for an increase in the ecological relations between the language practices and identity dispositions developed within instructional L2 contexts and the broader plurilingual communicative contexts of life outside of the academy. 
As mentioned at numerous points in this article, the developmentally successful use of Web 2.0 tools and immersive worlds will not be straightforward and cannot be taken for granted. However, the research and pedagogical reports discussed here strongly suggest a powerful potential of Web 2.0 and online immersive spaces for second language learning.

\section{NOTES}

${ }^{1}$ As measured by internetworldstats.com (http://internetworldstats.com).

2 See Tapscott (2000), McGrath (2004), Warschauer (2003), and Van Dijk (2005) for discussion of the digital divide in education, even in economically developed countries. While these factors also likely affect the perception and use of internet-mediated communicative tools, a discussion of these issues is beyond the scope of this analysis.

${ }^{3}$ Wikipedia (http://www.wikipedia.org), probably the most well known wiki, is a user-edited online encyclopedia founded in 2001 in which readers make changes and improve the content of the different texts.

${ }^{4}$ See Levy and Stone (2006) for a brief discussion in this area.

${ }^{5}$ In fact, of all the Web 2.0 technologies, wikis and blogs are arguably the most commonly used Web 2.0 tools in $\mathrm{L} 2$ education.

${ }^{6}$ These include, for example, pbwiki (http://pbwiki.com), QwikWiki (http://www.qwikiwiki.com), MediaWiki (http://www.mediawiki.org/wiki/MediaWiki), Google Docs (http://www.google.com/google-d-s/ intl/en/tour1.html), and wikispaces (http://www.wikispaces.com).

7 As a caveat, access does not necessarily indicate readership.

8 The collaborative aspect of social bookmarking is apparent when one understands that each URL connects the user's page to other users' del.icio.us pages who have bookmarked the same URL.

${ }^{9}$ In addition, we speculate that through examining the connections behind selected URLs and tags, learners might be more likely to find partners with whom to work on projects closely related to their own interests while also increasing their exposure to, and curiosity about, different topics.

10 To provide a concrete example, by connecting their pages to their blogs, students share their findings and links with the rest of the class, and even a wider community, at the same time that they increase the blog value as a written artifact in the social network. While working in collaborative projects in a wiki, students can easily have access to the shared information to elaborate their project. As the weeks, months, semesters, and years pass by, students will be able to add, delete, and constantly update sources of their interests. Social bookmarking has been little explored in L2 education.

11 "Pragmatics" addresses the various manners (i.e., linguistic and nonlinguistic) in which meaning is communicated and interpreted in interaction, as well as the sociocultural factors (individual and collective) which influence the communicated and interpreted messages (Crystal, 1997; LoCastro, 2003; Yule, 1996). Interlanguage pragmatics refers to the development of these abilities in a second language.

12 Thorne (2006) advocates for the importance of pragmatics in communicative competency by suggesting a re-orientation from a focus on $\mathrm{L} 2$ communicative competence to a focus on intercultural competence. This re-orientation emphasizes the critical connection between language and social practice as related to the negotiation of interactional patterns in intercultural communication.

${ }^{13}$ For an extensive discussion of these potential benefits, see Sykes (2008).

${ }^{14}$ For more information on Croquelandia see University of Minnesota Croquet Project (http://croquet. umn.edu). 
${ }^{15}$ Both Judd (1999) and Cohen (2005) offer instructional methodologies in pragmatics that fit within SIEs. Through different mechanisms, they both suggest the importance of a diversified look at pragmatics and the development of skills for using different pragmatic functions as opposed to teaching chunks or prescriptive formulas.

\section{REFERENCES}

Ahearn, L. (2001). Language and agency. Annual Review of Anthropology, 30, 109-37.

Alexander, B. (2006). Web 2.0. A new way of innovation for teaching and learning? EDUCAUSE Review, 41, 33-44. Retrieved November 30, 2007, from http://www.educause.edu/ir/library/pdf/ erm0621.pdf

Bachman, L. (1997). Fundamental considerations in language testing. Oxford: Oxford University Press.

Bardovi-Harlig, K. (2001). Evaluating the empirical evidence: Grounds for instruction in pragmatics? In K. Rose \& G. Kasper (Eds.), Pragmatics in language teaching (pp. 13-32). Cambridge: Cambridge University Press.

Belz, J. (2003). Linguistic perspectives on the development of intercultural competence in telecollaboration. Language Learning \& Technology, 7, 68-99. Retrieved March 11, 2008, from http://lt.msu. edu/vol7num2/belz

Belz, J. A., \& Thorne, S. L. (Eds.). (2006). Internet-mediated intercultural foreign language education. Boston: Thomson Heinle.

Bloch, J. (2007). Abdullah's blogging: A generation 1.5 student enters the blogosphere. Language Learning \& Technology, 11, 128-141. Retrieved March 11, 2008, from http://lt.msu.edu/vol11num2/ bloch/default.html

Brown, S., \& Adler, R. P. (2008). Minds on fire. Open education, the long trail, and learning 2.0. Educause, 43, 17-32. Retrieved January 25, 2008, from http://connect.educause.edu/Library/ EDUCAUSE+Review/MindsonFireOpenEducationt/45823

Bryant, T. (2006, September). Using World of Warcraft and other MMORPGs to foster a targeted, social, and cooperative approach toward language learning. Academic Commons. Retrieved October 6, 2006, from http://www.academiccommons.org/commons/essay/bryant-MMORPGs-for-SLA

Byram, M. (2000). Assessing intercultural competence in language teaching. Sprogforum, 18, 8-13.

Campbell, A. (2003). Weblogs for use with ESL classes. The Internet TESL Journal, 9. Retrieved March 16, 2007, from http://iteslj.org/Techniques/Campbell-Weblogs.html

Canale, M., \& Swain, M. (1980). Theoretical bases of communicative approaches to second language teaching and testing. Applied Linguistics, 1, 1-47.

Cassell, J., \& Jenkins, H. (Eds.). (1998). From Barbie to Mortal Combat: Gender and computer games. Cambridge: MIT Press.

Castells, M. (Ed.). (2004). The network society: A cross-cultural perspective. Northampton, MA: Edward Edgar.

Cheng, H. (2006). Warning: Adults only. Wired Magazine, 14. Retrieved March 11, 2008, from http:// www.wired.com/wired/archive/14.04/adults.html

Clark, H., \& Brennan, S. (1991). Grounding in communication. In L. B. Resnick, J. M. Levine, \& S. D. Teasley, (Eds.), Perspectives in socially shared cognition (pp. 127-150). Washington, DC: American Psychological Association.

Cohen, A. D. (1996). Developing pragmatic ability to perform speech acts. Studies in Second Language Acquisition, 18, 253-267. 
Cohen, A. D. (2004). Assessing speech acts in a second language. In B. Boxer \& A. D. Cohen (Eds.), Studying speaking to inform second language learning (pp. 302-327). Clevedon, England: Multilingual Matters.

Cohen, A. D. (2005). Strategies for learning and performing L2 speech acts. Intercultural Pragmatics, 2, 275-301.

Crystal, D. (Ed.). (1997). The Cambridge encyclopedia of language (2nd ed.). New York: Cambridge University Press.

de Freitas, S. (2006). Learning in immersive worlds: A review of game-based learning. Bristol, UK: Joint Information Systems Committee (JISC) E-Learning Programme. Retrieved March 11, 2008, from http://www.jisc.ac.uk/whatwedo/programmes/elearning_innovation/eli_outcomes/GamingRe port.aspx

Dror, I. (Ed.). (2007). Cognitive technologies and the pragmatics of cognition. Amsterdam: John Benjamins Publishing.

Ducate, N., \& Lomicka, L. (2005). Exploring the blogosphere: Use of web logs in the foreign language classroom. Foreign language annals, 38, 410-421.

Elola, I., \& Oskoz, A. (2008). Blogging: Fostering intercultural competence development in foreign language and study abroad contexts. Manuscript submitted for publication.

Farabaugh, R. (2007). The isle is full of noises: Using wiki software to establish a discourse community in a Shakespeare classroom. Language Awareness, 16, 41-56.

Farabaugh, P., Farabaugh, R., \& Freeland, S. (2005, November). Using wikis in teaching and learning. Paper presented at the TLT Brown bag, University of Maryland Baltimore County, Baltimore, MD.

Fidalgo-Eick, M. (2006, May). Blogs in the foreign language classroom. Paper presented at the annual conference of the Computer Assisted Language Instruction Consortium, Manoa, HI.

Furstenberg, G., Levet, S., English, K., \& Maillet, K. (2001). Giving a virtual voice to the silent language of culture: The CULTURA project. Language Learning \& Technology, 5, 2001. Retrieved March 11, 2008, from http://llt.msu.edu/vol5num1/furstenberg/default.html

García-Carbonell, A., Montero, B., Rising, B., \& Watts, F. (2001). Simulation/gaming and the acquisition of communicative competence in another language. Simulation \& Gaming, 32, 481-491.

Gee, J. (2003). What video games have to teach us about learning and literacy. New York: Palgrave Macmillan.

Gee, J. (2005). Why video games are good for your soul. Sydney, Australia: Common Ground.

Goodwin-Jones, R. (2003). Blogs and wikis: Environments for on-line collaboration. Language Learning \& Technology, 7, 12-16. Retrieved March 11, 2008, from http://lt.msu.edu/vol7num2/emerg ing

Godwin-Jones, R. (2005). Skype and podcasting: Disruptive technologies for language learning. Language Learning \& Technology, 9, 9-12. Retrieved March 11, 2008, from http://ltt.msu.edu/vol9 num3/emerging/default.html

Hymes, D. (1972). Toward ethnographies of communication: The analysis of communicative events. In P. Giglioli (Ed.), Language and social context (pp. 21-43). Harmondsworth, UK: Penguin.

Jaschik, S. (2007, January 26). A stand against Wikipedia. Inside HigherEd. Retrieved April 4, 2008, from http://www.insidehighered.com/news/2007/01/26/wiki

Jenkins, H. (2006). Convergence culture: Where old and new media collide. New York: New York University Press. 
Jenkins, H. (2008, January). What Wikipedia can teach us about new media literacies. Plenary presented at EDUCAUSE, Education Learning Initiative, San Antonio, TX. Available at http://www. educause.edu/Program/13300?PRODUCT_CODE=ELI081/GS01

Jenkins, H., \& Squire, K. (2004). Harnessing the power of games in education. Insight, 3, 5-33.

Judd, E. (1999). Some issues in the teaching of pragmatic competence. In E. Hinkel (Ed.), Culture in second language teaching and learning (pp. 152-166). Cambridge: Cambridge University Press.

Kasper, G. (1997). Can pragmatic competence be taught? (Network \#6). Honolulu: University of Hawai'i, Second Language Teaching \& Curriculum Center. Retrieved November 30, 2007, from http:// nflrc.hawaii.edu/NetWorks/NW06/default.html

Kost, C. (2007, May). Using wikis for a collaborative writing project. Paper presented at the annual conference of the Computer Assisted Language Instruction Consortium, Texas State University, San Marcos, TX.

Kushner, D. (2006). Good Nintendog! Roll over, Rover. A new breed of games is building deep emotional bonds and rival the best puppy love. Wired Magazine, 14. Retrieved March 11, 2008, from http://www.wired.com/wired/archive/14.04/nintendog.html

Lamb, B. (2004). Wide open spaces wikis: wikis ready or not. EDUCAUSE Review, 39, 36-46. Retrieved November 30, 2007, from http://www.educause.edu/ir/library/pdf/erm0452.pdf

Lankshear, C., \& Knobel, M. (2007). Sampling "the new" in new literacies. In M. Knobel \& C. Lankshear (Eds.), A new literacies sampler (pp. 1-24). New York: Peter Lang.

Lantolf, J. P., \& Thorne, S. L. (2006). Sociocultural theory and the genesis of second language development. Oxford: Oxford University Press.

Levy, S. \& Stone, B. (2006, April 3). The new wisdom of the web. Newsweek. Retrieved April 4, 2008, from http://www.newsweek.com/id/45976

LoCastro, V. (2003). An introduction to pragmatics: Social action for language teachers. Ann Arbor, MI: The University of Michigan Press.

Lomicka, L., Lord, G., Ducate, L., \& Arnold, N. (2007, May). Teaching, learning and collaborating: A foreign language teacher wiki community. Paper presented at the annual conference of the Computer Assisted Language Instruction Consortium, Texas State University, San Marcos, TX.

Márquez-Reiter, R., \& Placencia, M. (2005). Spanish pragmatics. New York: Palgrave Macmillan.

McGrath, D. (2004). Equity revisited: PBL and the digital divide. Learning and Leading with Technology, 32, 36-39. Retrieved November 30, 2007, from http://www.iste.org/Content/NavigationMenu/ Publications/LL/LLIssues/Volume_32_2005_2004_Joctober_No_2_/October_2004.htm

Mistral, P. (2007). Second Life ballet fills the SIM-Linden suggests selling tickets. Second Life Herald. Retrieved March 11, 2008, from http://www.secondlifeherald.com/slh/2007/02/olmannen_pre mie.html

Nardi, B., Ly, S., \& Harris, J. (2007). Learning conversations in World of Warcraft. In The Proceedings of the 2007 Hawaii International Conference on Systems Science. New York: IEEE Press.

National Summit on Educational Gaming. (2005). National Summit on Educational Games Fact Sheet. Retrieved March 11, 2008, from http://www.fas.org/gamesummit/Resources/Fact\%20Sheet.pdf

Oskoz, A., \& Elola, I. (2008) Meeting at the wiki: The new arena for collaborative writing in foreign language courses. Manuscript in preparation.

Prensky, M. (2001). Digital game-based learning. St. Paul, MN: Paragon House.

Richardson, W. (2006). Blogs, wikis, podcasts, and other powerful web tools For classrooms. Corwin Press: Thousand Oaks, CA. 
Roever, C. (2004). Difficulty and practicality in tests of interlanguage pragmatics. In B. Boxer \& A. D. Cohen (Eds.), Studying speaking to inform second language learning (pp. 283-301). Clevedon, England: Multilingual Matters.

Rose, K. (2005). On the effects of instruction in second language pragmatics. System, 33, 385-99.

Rose, K., \& Kasper, G. (Eds.). (2001). Pragmatics in language teaching. Cambridge: Cambridge University Press.

Rosenbloom, S. (2006, November 16). Corners: In certain circles, two is a crowd. The New York Times. Retrieved March 11, 2008, from http://www.nytimes.com/2006/11/16/fashion/16space.html?_r $=1 \&$ oref $=$ slogin

Sadler, R. (2007, November 30). Ethics in Second Life. Paper presented at the CALL Club, Iowa State University, Ames, IA.

Salaberry, R., \& Cohen, A. D. (2006). Testing Spanish. In R. Salaberry \& B. Lafford (Eds.), The art of teaching Spanish: Second language acquisition from research to praxis. Washington, DC: Georgetown University Press.

Sawyer, B. (2005, summer). Games leaders play. Threshold, 26-29. Retrieved March 11, 2008, from http://www.ciconline.org/thresholdsummer05

Second Life Herald. (2006). Retrieved March 11, 2008, from http://www.secondlifeherald.com/slh/2006/ 01/index.html

Second Life Herald. (2007). Retrieved March 11, 2008, from http://foo.secondlifeherald.com/slh/2007/01/ oped_linden_oh_.html

Shamoon, E. (2006). 3BR w/VU of asteroid belt: One man's plan to turn virtual real estate into cold hard cash. Wired Magazine, 14. Retrieved March 11, 2008, from http://www.wired.com/wired/ archive/14.04/station.html

Slater, M., Antley, A., Davison, A., Swapp, D., Guger, C., Barker, C., et al. (2006). A virtual reprise of the Stanley Milgram experiments. PLoSOne, 1, e39. Retrieved March 11, 2008, from http://www. plosone.org/article/info:doi\%2F10.1371\%2Fjournal.pone.0000039

Steinkuehler, C. A. (2004). Learning in massively multiplayer online games. In Y. B. Kafai, W. A. Sandoval, N. Enyedy, A. S. Nixon, \& F. Herrera (Eds.), Proceedings of the Sixth International Conference of the Learning Sciences (pp. 521-528). Mahwah, NJ: Lawrence Erlbaum Associates.

Steinkuehler, C. A. (2006). Massively multiplayer online videogaming as participation in a discourse. Mind, Culture, \& Activity, 13, 38-52.

Steinkuehler, C. (2007). Massively multiplayer online gaming as a constellation of literacy practices. eLearning, 4, 297-318.

Sykes, J. M. (2005). Synchronous CMC and pragmatic development: Effects of oral and written chat. CALICO Journal, 22, 399-432. Retrieved March 11, 2008, from https://calico.org/p-5-Calico\%20 Journal.html

Sykes, J. M. (2008). A dynamic approach to social interaction: SCMC, synthetic immersive environments \& Spanish pragmatics. Unpublished doctoral dissertation, University of Minnesota, Minneapolis, MN.

Tapscott, D. (2000). The digital divide. In The Jossey-Bass Reader on Technology and Learning (pp. 127-154). San Francisco: Jossey-Bass.

Thorne, S. L. (2000). Beyond bounded activity systems: Heterogeneous cultures in instructional uses of persistent conversation. In The Proceedings of the Thirty-Third Hawaii International Conference on Systems Science. New York: IEEE Press. 
Thorne, S. L. (2003). Artifacts and cultures of use in intercultural communication. Language Learning \& Technology, 7, 38-67. Retrieved March 11, 2008, from http://lt.msu.edu/vol7num2/thorne/ default.html

Thorne, S. L. (2006). Pedagogical and praxiological lessons from internet-mediated intercultural foreign language education research. In J. Belz \& S. Thorne (Eds.), Internet-mediated intercultural foreign language education (pp. 2-30). Boston: Thomson Heinle.

Thorne, S. L. (2008a). Computer-mediated communication. In N. Hornberger \& N. Van Duesen-Scholl (Eds.), Encyclopedia of language and education: Vol. 4. Second and foreign language education (pp. 325-336). New York: Springer/Kluwer.

Thorne, S. L. (2008b). Mediating technologies and second language learning. In D. Leu, J. Coiro, C. Lankshear \& M. Knobel (Eds.), Handbook of research on new literacies (pp. 417-449). Mahwah, NJ: Lawrence Erlbaum Associates.

Thorne, S. L. (2008c). Transcultural communication in open internet environments and massively multiplayer online games. In S. Magnan (Ed.), Mediating discourse online (pp. 305-327). Amsterdam: John Benjamins.

Thorne, S. L., \& Black, R. W. (2007). New media literacies, online gaming, and language education. (CALPER Working Paper Series, No. 8). The Pennsylvania State University: Center for Advanced Language Proficiency Education and Research.

Thorne, S. L., \& Black, R. (2008). Language and literacy development in computer-mediated contexts and communities. Annual Review of Applied Linguistics, 27, 133-160.

Thorne, S. L., \& Payne, J. S. (2005). Evolutionary trajectories, internet-mediated expression, and language education. CALICO Journal, 22, 371-97. Retrieved March 11, 2008, from https://calico. org/p-5-Calico\%20Journal.html

Thorne, S. L. \& Reinhardt, J. (2008). "Bridging activities," new media literacies and advanced foreign language proficiency. The CALICO Journal, 25(3), 558-572. Retrieved May 1, 2008, from https:// calico.org/p-5-Calico\%20Journal.html

Van Dijk, J. (2005). The deepening divide: Inequality in the information society. London: Sage.

Wang, H., Lu, C., Yang, J., Hu, H., Chiou, G., Chiang, Y., et al. (2005). An empirical exploration of using wiki in an English as a second language course. In P. Goodyear, D. G. Sampson, D. J.-T. Yang, T. Okamoto, R. Hartley, \& N. S. Chen (Eds.), Proceedings of the Fifth IEEE International Conference on Advanced Learning (pp. 155-157). Los Alamitos, CA: IEEE Computer Society. Retrieved April 4, 2008, from http://ieeexplore.ieee.org/iel5/10084/32317/01508634.pdf?arnumber $=1508634$

Warschauer, M. (2003). Technology and social inclusion: Rethinking the digital divide. Cambridge: MIT Press.

Wilcox, L., Allison, R., Elfassy, S., \& Grelik, C. (2006). Personal space in virtual reality. ACM Transactions on Applied Perceptions, 3, 412-28.

Yule, G. (1996). Pragmatics. Oxford: Oxford University Press.

\section{AUTHORS' BIODATA}

Julie M. Sykes is a doctoral candidate in the Department of Spanish and Portuguese at the University of Minnesota where she specializes in Spanish Applied Linguistics, emerging technologies/CALL, and L2 pragmatic acquisition. She also holds a graduate certificate in School Technology Leadership from the University of Minnesota. Julie's most recent project entails the creation, implementation, and empirical investigation of the first synthetic immersive environment for learning Spanish pragmatics, Croquelandia. Sykes has presented extensively 
and published various articles on CALL-related topics including synchronous computer-mediated communication and pragmatic development, gaming and CALL, and lexical acquisition in digitally mediated environments.

Ana Oskoz is Assistant Professor at the University of Maryland Baltimore County (UMBC). She obtained her Ph.D. from the University of Iowa in Foreign Language Education and currently teaches undergraduate and graduate courses in Spanish language and second language acquisition. Her most recent research focuses on the use of Web 2.0 applications, such as wikis and blogs, in the foreign language classroom. Ana Oskoz has presented extensively nationally and internationally and published on CALL-related topics.

Steven L. Thorne is Assistant Professor in the Department of Applied Linguistics and Associate Director of the Center for Language Acquisition at the Pennsylvania State University. He also serves as the Advisor for Mediated Learning at the Center for Advanced Language Proficiency Education and Research (http://calper.la.psu.edu). His interests include new media literacies, CALL, intercultural communication, and projects that engage cultural-historical activity theory, contextual traditions of language analysis, and usage-based approaches to language development. His book length works include a co-edited volume, Internet-mediated Intercultural Foreign Language Education (Thomson/Heinle, 2006) and the co-authored monograph Sociocultural Theory and the Genesis of Second Language Development (Oxford University Press, 2006).

\section{AUTHORS' ADDRESSES}

Julie M. Sykes

Department of Spanish \& Portuguese

University of Minnesota

9 Pleasant Street S.E. Minneapolis, MN 55455 USA

Phone: 6126245529

Email: sykes030@umn.edu

Ana Oskoz

Department of Modern Languages and Linguistics

University of Maryland Baltimore County (UMBC)

1000 Hilltop Circle

Baltimore, Maryland 21250

Phone: 4104552997

Fax: 4104551025

Email: aoskoz@umbc.edu

Steven L. Thorne

Department of Applied Linguistics

The Pennsylvania State University

305 Sparks

University Park, PA 16802

Phone: 8148637036

Fax: 8148657944

Email: sthorne@psu.edu 